DOI: $10.18276 /$ sip.2016.43/3-12

\title{
Anna Jasiulewicz*
}

Szkoła Główna Gospodarstwa Wiejskiego w Warszawie

\section{MOTYWY I BARIERY KONSUMPCJI INNOWACYJNYCH PRODUKTÓW ŻYWNOŚCIOWYCH}

\begin{abstract}
Streszczenie
W artykule dokonano przeglądu literatury dotyczącej problematyki uwarunkowań akceptacji innowacyjnych produktów żywnościowych przez konsumentów. Przedstawiono również wybrane wyniki własnych badań ankietowych prezentujące motywy zakupu oraz bariery konsumpcji tych produktów. Z analizy literatury przedmiotu i rezultatów badań wynika, że motywem lub barierą mogą być cechy samej innowacji, cechy konsumenta oraz cechy środowiska.
\end{abstract}

Słowa kluczowe: innowacyjny produkt żywnościowy, konsument, motywy, bariery konsumpcji

\section{Wstęp}

Opracowanie innowacyjnych produktów spożywczych będących odpowiedzią na potrzeby konsumentów może dotyczyć niewielkiej zmiany istniejących dóbr, lecz także wprowadzania na rynek zupełnych nowości (Panasiewicz, Mazur, Nadulski, Zawiślak, Sobczak, 2014, s. 15). Konsument jako nowy produkt żywnościowy postrzega taki, którego wcześniej nie mógł kupić. Dla producenta „nowy produkt” to często synonim wyrobu nieoferowanego wcześniej przez niego na rynku. Zazwyczaj nowe produkty

\footnotetext{
*Adres e-mail: anna_jasiulewicz@sggw.pl; annajasiulewicz@gmail.com.
} 
pojawiające się w sprzedaży są wynikiem naśladowczych działań producentów, na przykład dzięki kupnie patentów, licencji lub know-how (Rudnicki, 2012, s. 138).

Większość innowacji żywnościowych powstaje w wyniku połączenia wybranych zabiegów technologicznych oraz modyfikacji recepturowych. $Z$ reguły nowy produkt żywnościowy jest efektem rozbudowy istniejącej linii produktów poprzez wprowadzenie nowych aromatów, smaków, nowej tekstury, funkcjonalnych opakowań (o nowej szacie graficznej, innych wymiarach), zmianę składu (np. produkty o niższej zawartości cukru). Często produkty poddawane są modyfikacji, która nadaje im formę żywności funkcjonalnej poprzez dodatek nowych składników (zamienników tłuszczu, błonnika pokarmowego, różnych witamin) lub wygodnej, która charakteryzuje się nowymi sposobami przygotowania albo serwowania produktu (Makała, Olkiewicz, 2004, s. 122).

Dla realizacji celów przeprowadzonego badania własnego została zaproponowana i umieszczona $w$ kwestionariuszu ankiety następująca definicja innowacyjnego produktu żywnościowego: „nowy, nieistniejący dotychczas na rynku produkt żywnościowy lub wzbogacony i ulepszony już istniejący produkt żywnościowy (modyfikacja składu produktu lub opakowania - np. łatwy do przygotowania, do spożycia i przechowywania); mający pozytywny wpływ na zdrowie, kondycję fizyczną i intelektualną; produkt modyfikowany genetycznie; produkt etniczny znany tylko pewnym grupom ludzi; produkt ekologiczny”. Definicja odnosi się do grup produktów zaproponowanych jako żywność innowacyjna przez Tourillę, Läahtenmakiego, Pohjalainena i Lottiego (2001).

Adaptacja innowacji przez konsumentów jest badana z perspektywy różnych dyscyplin naukowych. Można dostrzec różnice w analizach na poziomie makroekonomicznym, gdzie uwaga skupiona jest na kosztach i korzyściach dyfuzji innowacji, oraz na poziomie mikroekonomicznym, gdzie w centrum zainteresowania badawczego jest człowiek, jego postawa oraz motywy i bariery zakupu innowacji (Ronteltap, Van Trijp, Renes, Frewer, 2007, s. 1-17).

\section{Materiały i metodyka}

Artykuł ma w przeważającej mierze charakter przeglądowy. Do jego napisania wykorzystano polską i zagraniczną literaturę przedmiotu poświęconą problematyce uwarunkowań akceptacji innowacyjnych produktów żywnościowych przez konsumentów. Omówiono czynniki związane z produktem, konsumentem, środowiskiem 
oraz komunikacją marketingowa i społeczną, które mogą stanowić bariery konsumpcji innowacji bądź motywy do ich zakupu.

W kontekście rozważań teoretycznych zaprezentowano także wybrane wyniki własnego badania ankietowego przeprowadzonego w listopadzie 2015 roku na próbie 342 respondentów, będącego częścią badań międzynarodowych służących porównawczej analizie zachowań polskich i ukraińskich konsumentów na rynku innowacyjnych produktów spożywczych. Przedstawione wyniki odnoszą się wyłącznie do motywów i barier konsumpcji tych produktów przez polskich konsumentów i nie są prezentowane w kontekście ich profilu demograficzno-społecznego, lecz uogólnione na całą badaną populację.

Badanie zrealizowano w Katedrze Polityki Europejskiej, Finansów Publicznych i Marketingu (KPEFPiM) SGGW. Badanie zostało przeprowadzone przy użyciu ankiety internetowej zamieszczonej na portalu ankietka.pl. Wyniki badań nie są reprezentatywne, należy je więc interpretować z dużą ostrożnością, gdyż wyrażają jedynie opinie tych uży tkowników internetu, którzy chcieli wziąć udział w ankiecie.

\section{Uwarunkowania akceptacji innowacyjnych produktów żywnościowych}

$\mathrm{Z}$ analizy literatury przedmiotu wynika, że o adaptacji nowości produktowych decyduje wiele aspektów, między innymi: cechy samej innowacji, cechy konsumenta, cechy środowiska (np. system społeczny, komunikacja społeczna i marketingowa). Obok czynników obiektywnych ważne są również czynniki subiektywne, które odzwierciadlają odbiór różnych faktów przez konsumenta (Jeżewska- Zychowicz, 2012, s. 28).

\subsection{Cechy związane $z$ produktem}

Cechy innowacji produktowych w dużej mierze decydują o pozytywnej lub negatywnej postawie konsumenta wobec nowego produktu. Funkcjonalność opakowania, cena, smak, wygląd ogólny to cechy uwzględniane w badaniach nad adaptacją innowacyjnych produktów żywnościowych. Także postrzegany przez konsumentów stopień innowacyjności produktu może wpłynąć na jego akceptację lub jej brak (Lowe, Alpert, 2015, s. 1-14).

Wielu współczesnych konsumentów ocenia produkty na podstawie ich zdrowotnych i odżywczych cech jakości. Z szerokiej oferty produktów konsumenci wy- 
bierają coraz częściej takie, które nie zawierają chemicznych substancji konserwujących, sztucznych barwników, są bogate w witaminy, błonnik, minerały, ubogie w tłuszcze i cukry. Takie produkty są często określane mianem innowacyjnej żywności (Górska-Warsewicz, 2003).

Ceny produktów innowacyjnych również wpływają na decyzje nabywcze konsumentów. Zazwyczaj wyższe ceny przesądzają o zmniejszeniu zakupów realizowanych przez konsumentów (Laskowski, Górska-Warsewicz, 2014).

\subsection{Cechy związane $z$ konsumentem}

Osobiste preferencje konsumentów wpływają na sposób interpretowania wartości innowacyjnego produktu przez konsumentów. Przedmiotem naukowych dyskusji jest rola cech społeczno-demograficznych konsumentów (takich jak wiek, poziom edukacji, dochód) oraz cech psychograficznych (innowacyjność, przywództwo opinii, zaangażowanie) w przyjmowaniu innowacji (Park, Gunn, Lee, Shim, 2015, s. 115-124). Dotychczasowe badania nie pozwalają jednoznacznie określić, w jakim stopniu wpływają one na adopcję innowacji, jednak wielu badaczy stwierdziło, iż odgrywają one znaczącą rolę w zakupie nowych produktów. Przykładowo Labay i Kinear (1981) uważają, że wykształcenie, wiek, faza życia, czynność zawodowa, jak również dochód wpływają na akceptację nowych produktów żywnościowych.

Reakcje konsumentów na nową żywność są warunkowane w dużym stopniu przez ich cechy psychologiczne. Nowość bodźców, których źródłem często są innowacyjne produkty, u niektórych może powodować chęć poznania, zaś u innych brak takiej potrzeby. Uwarunkowane jest to skłonnością przystosowawczą oraz ciekawością człowieka (Jeżewska-Zychowicz, 2007). Nabywca dąży przede wszystkim do odczuwania przyjemności, pozytywnych emocji, unika negatywnych. Maksymalna chęć poznawcza powstaje przy najmniejszym poziomie poczucia lęku lub jego braku. Arts, Frambach i Bijmolt (2011) twierdzą, że konsumenci wykazują wyższy stopień adaptacji innowacji, które są bardziej kompleksowe, lepiej dopasowane do potrzeb, co redukuje odczuwaną niepewność. Niektórzy konsumenci mają wrodzoną tendencję lękową, W związku z czym ich poziom otwartości na produkty innowacyjne jest bardzo niski. Różnice pomiędzy konsumentami wynikające z pobudzenia lub podatności na lęk warunkują ich reakcje na nowe produkty (Jeżewska-Zychowicz, 2014, s. 5-17).

Także stopień innowacyjności konsumentów to aspekt wpływający na akceptację innowacji na ryku. Adaptacja nowego produktu jest utrudniona, jeżeli 
osoba nie zna podobnej żywności, jak również charakteryzuje się neofobią żywieniową (Jasiulewicz, 2014, s. 251-264).

\subsection{Czynniki związane ze środowiskiem. Komunikacja społeczna}

Akceptacja innowacji w pewnym stopniu zależy od charakteru gospodarki, systemu politycznego i społecznego, w którym ma miejsce wybór produktów żywnościowych. Dla akceptacji innowacyjnych produktów istotne też jest to, jak bardzo odmienne są od aktualnie stosowanych oraz kto i w jaki sposób informuje o tych produktach konsumentów. Społeczne zaufanie oznaczające gotowość do polegania na osobach, które są odpowiedzialne za podejmowanie decyzji dotyczących kierowania, zarządzania technologiami, okazuje się ważnym kryterium postrzegania zarówno korzyści, jak i ryzyka w odniesieniu do wielu technologii (Jeżewska-Zychowicz, 2014, s. 5-17) Stopień akceptacji nowych technologii wytwarzania żywności (np. modyfikacja genetyczna, enzymy) wpływa na stopień adaptacji innowacyjnych produktów (Loebinitz, Grunert, 2015, s. 725-741)

Postępujące zmiany w zachowaniach konsumentów są często skutkiem i czynnikiem sprawczym pojawienia się pewnych trendów. Wielu konsumentów zwraca uwagę na aspekty zdrowotne i środowiskowe żywności. Rosnące znaczenie wysokojakościowej żywności staje się jednym z elementów dzisiejszego stylu życia. Dlatego też nabywcy często poszukują nowego rodzaju żywności, która spełni ich oczekiwania (Adamowicz, 2008, s. 221-231).

Znaczenie komunikacji interpersonalnej w procesie rozpowszechniania się zarówno informacji marketingowej, jak i samych innowacji jest bardzo ważne. Wywieranie wpływu społecznego jednych osób na drugie jest określane mianem kształtowania opinii. Niektóre jednostki są częściej proszone o radę czy udzielanie informacji niż pozostałe. Nieformalna komunikacja zachodzi poprzez rozmowę twarzą w twarz bądź za pośrednictwem internetu, gdzie konsumenci, na przykład na forach, czatach, dzielą się swoimi opiniami na temat nowych produktów i rekomendują je bądź nie innym potencjalnym konsumentom. Osoby, które udzielają takich informacji, a w konsekwencji również wpływają na decyzje zakupowe, określa się mianem liderów opinii (Kraszewska, 2011, s. 74-85).

Znaczącą rolę w przekazywaniu informacji, wiedzy o innowacyjnych produktach odgrywają także maweni rynkowi (tzw. wyrocznie rynkowe) (Jasiulewicz, 2014, s. 251-264). W przeciwieństwie do liderów opinii są raczej ekspertami zakupowymi, 
posiadają rozległą wiedzę oraz doświadczenie z rynkiem, jak również zachowaniem na rynku, a nie w konkretnej jednej dziedzinie. Niezwykle chętnie poszukują nowości rynkowych i informacji z nimi związanych, korzystając z wszelakich źródeł informacji marketingowej, dodatkowo przekazując te informacje dalej do innych użytkowników (Kraszewska, 2011, s. 74-85).

\section{Motywy i bariery konsumpcji. Wyniki badań ankietowych}

Urozmaicenie diety konsumentów wydaje się być istotnym motywem zakupu nowej żywności pojawiającej się na rynku. Respondenci poproszeni o wskazanie trzech głównych powodów zakupu i spożycia innowacyjnych produktów deklarują przede wszystkim, iż lubią urozmaicone żywienie (82\%) i interesują ich nowości (74\%). Można więc stwierdzić, że głównymi uwarunkowaniami akceptacji innowacyjnych produktów żywnościowych są cechy związane z konsumentem, takie jak neofilia żywieniowa, która jest przeciwieństwem neofobii, oraz innowacyjność konsumentów.

Żywność innowacyjna (taka jak np. żywność funkcjonalna) jest postrzegana przez część konsumentów jako posiadająca pozytywne wartości zdrowotne. Ważnym powodem spożywania innowacji jest w opinii respondentów ich dbałość o zdrowie (63\%) oraz zainteresowanie sprawami żywienia (39\%). Korzystny wpływ produktu na organizm zachęca do kupna nowości aż 79\% badanych. Są to cechy związane z produktem (wartości odżywcze, obniżona kaloryczność, bakterie probiotyczne itp.) oraz czynniki związane ze środowiskiem (zdrowy styl życia jako współczesny trend). Inne ważne czynniki związane z produktem, które są motywami zakupu, to ekologiczność innowacji (58\%), zaskakujący smak (47\%), funkcjonalne opakowanie (36\%).

Nieco mniej zauważalna w odpowiedziach konsumentów jest rola komunikacji marketingowej i społecznej jako czynnika wpływającego na akceptację innowacji. $1 / 3$ respondentów (33\%) motywuje do kupna nowych produktów intensywna promocja. Według 24\% ankietowanych jest to czynnik istotny, a według $15 \%$ bardzo istotny. Dwanaście procent respondentów jako jeden z głównych powodów spożycia wskazuje oczekiwania bliskich, a 8\% chęć zaimponowania otoczeniu. Jednak w pytaniu dotyczącym źródeł, z których respondenci czerpią informacje na temat innowacyjnej żywności, 35\% wskazuje rodzinę i znajomych jako istotne źródło, a $15 \%$ jako bardzo istotne.

Podstawowa bariera zakupu i konsumpcji innowacyjnej żywności jest związana przede wszystkim z cechami produktu, czyli jego zbyt wysoką ceną (81\%). Inne 
bariery są związane ze środowiskiem i funkcjonującą w jego zakresie komunikacją marketingową i społeczną. Respondenci jako przeszkodę traktują czynnik związany z ofertą rynkową, czyli zbyt słabą dostępność innowacji żywnościowych na rynku (63\%) oraz zbyt małą ilość nowości na rynku (16\%). Blisko połowa respondentów (47\%) uważa, że informacje płynące z rynku na temat innowacji są niewystarczające, a $22 \%$ badanych ogranicza zakup nowości, ponieważ nie są polecane przez ekspertów w zakresie żywienia i lekarzy. Czynnikiem utrudniającym akceptację mogą być też cechy konsumenta, na przykład neofobia żywieniowa i preferowanie żywności tradycyjnej, do której respondenci są przyzwyczajeni (20\%).

\section{Podsumowanie}

Na podstawie analizy literatury przedmiotu i wyników badań można wskazać, że motywem lub barierą nabywania i konsumpcji innowacyjnych produktów żywnościowych mogą być cechy samej innowacji (takie jak cena, funkcjonalność zdrowotna, wygodne opakowanie, smak, ekologiczność), cechy konsumenta (neofilia, neofobia, innowacyjność) oraz cechy środowiska (trendy w zakresie konsumpcji, komunikacja marketingowa i społeczna).

\section{Literatura}

Adamowicz, M. (2008). Zachowanie konsumentów w procesach adopcji innowacji na rynku owoców. W: M. Adamowicz (red.), Innowacje i innowacyjność w sektorze agrobiznesu (s. 221-231). Warszawa: Wyd. SGGW.

Arts, J.W.C., Frambach, R.T., Bijmolt, T.H.A. (2011). Generalizations on Consumer Innovation Adoption: A Meta-Analysis on Drivers of Intention and Behavior. International Journal of Market Research, 28 (2), 134-144.

Górska-Warsewicz, H. (2003). Innowacje produktowe w opinii konsumentów. Przemyst Spożywczy, 3, 34-36.

Jasiulewicz, A. (2014). Zachowania konsumentów na rynku innowacyjnych produktów żywnościowych. Marketing i Rynek, 6, 251-264.

Jeżewska-Zychowicz, M. (2007). Zachowania żywieniowe i ich uwarunkowania. Warszawa: Wyd. SGGW.

Jeżewska-Zychowicz, M. (2012). Uwarunkowania akceptacji nowych produktów żywnościowych. W: A. Kropiwiec (red.), Akceptacja nowych produktów żywnościowych i jej uwarunkowania. Warszawa: Wyd. SGGW. 
Jeżewska-Zychowicz, M. (2014). Uwarunkowania akceptacji konsumenckiej innowacyjnych produktów żywnościowych. Żywność. Nauka. Technologia. Jakość, 6 (97), 5-17.

Labay, D.G., Kinnear, T.C. (1981). Exploring the Consumer Decision Process in the Adoption of Solar Energy Systems. Journal of Consumer Research, 8, 271-276.

Laskowski, W., Górska-Warsewicz, H. (2014). Czynniki ekonomiczne determinujące wybory konsumenckie. W: Gęstość odżywcza spożywanych racji pokarmowych w Polsce. Próba oszacowania i oceny wptywu statusu ekonomicznego (s. 25-34). Warszawa: Wyd. Laskowski.

Loebinitz, N., Grunert, K.G. (2015). Evaluative Conditioning of Food Technologies. Psychology \& Marketing, 32 (7), 725-741.

Lowe, B., Alpert, F. (2015). Forecasting Consumer Perception of Innovativeness. Technovation, 45-46, 1-14.

Makała, H., Olkiewicz, M. (2004). Zasady opracowania nowych produktów z uwzględnieniem oczekiwań konsumentów na przykładzie mięsa i jego przetworów. Żywność. Nauka. Technologia. Jakość, 1 (38), 120-133.

Kraszewska, M. (2011). Determinanty akceptacji innowacji przez konsumentów na rynku owoców i przetworów owocowych - przegląd literatury. W: M. Adamowicz (red.), Konsumenci a innowacje na rynku owoców (s. 74-85). Warszawa: Wyd. SGGW.

Panasiewicz, M., Mazur, J., Nadulski, R., Zawiślak K., Sobczak P. (2014). Wybrane aspekty innowacyjności oraz zasad i procedur opracowywania nowego produktu spożywczego. Inżynieria Przetwórstwa Spożywczego, 3 (11), 15-19.

Park, J., Gunn, F., Lee, Y.H., Shim, S. (2015). Consumer Acceptance of Revolutionary Technology-Driven Product: The Role of Adoption in the Industrial Design Development. Journal of Retailing and Consumer Services, 26, 115-124.

Ronteltap, A., Van Trijp, J.C.M., Renes, R.J., Frewer, L.J. (2007). Consumer Acceptance of Technology-Based Food Innovations: Lessons for the Future of Nutrigenomic. Appetite, 49, 1, 1-17.

Rudnicki, L. (2012). Konsument w polityce rozwoju nowego produktu. Zeszyty Naukowe Małopolskiej Wyższej Szkoły Ekonomicznej w Tarnowie, 20 (1), 137-147.

Tuorilla, H., Läahtenmaki, L., Pohjalainen, L., Lotti, L. (2001). Food Neophobia Among the Finns and Related Responses to Familiar and Unfamiliar Foods. Food Quality and Preference, 12 (1), 29-37. 


\title{
MOTIVES AND BARRIERS TO INNOVATIVE FOOD CONSUMPTION
}

\begin{abstract}
This article reviews the literature on the issue of innovative food products acceptance conditions by consumers. It also presents selected results of the survey showing the purchase motives and barriers to consumption of these products. The literature analysis and research results show that motive or barrier may be innovations features, consumer features and environmental characteristics.
\end{abstract}

Translated by Anna Jasiulewicz

Keywords: innovative foodstuff, consumer, motives, barriers

JEL Codes: D10, M30 
